Walisongo Law Review (Walrev), Vol 1 No. 2 (2019)

DOI: 10.21580/Walrev/2019.1.2.4815

Copyright @ 2019 Walisongo Law Review (Walrev)

Walisongo Law Review

\title{
Philosophical Study of Hans Kelsen's Thoughts on Law and Satjipto Rahardjo's Ideas on Progressive Law
}

\author{
Muhammad Harun \\ Afiliasi: Universitas Islam Negeri (UIN) Walisongo, Semarang \\ e-mail: harundosen@gmail.com
}

\begin{abstract}
The purpose of this paper is to compare and evaluate the thoughts of Hans Kelsen with Satjipto Raharjo. Both offer their respective theories, namely Hans Kelsen's pure legal theory and Satjipto Rahardjo's progressive law. In this theory, both of them base their philosophical approach. After reviewing, the theories of these two figures are relevant for interpreting the law. This paper uses a critical paradigm with a combination of normative or doctrinal and sociological or non-doctrinal approaches. The results showed that Hans Kelsen directed his mind that legal positivism considers moral speech, values are finished and final when it comes to the formation of positive law. Pure Legal Theory is not a perfect copy of transcendental ideas, but it does not try to see the law as a posterity of justice. While Rahardjo's progressive law rests on the aspects of rules and behavior. Regulations will build a positive and rational legal system. While the behavioral or human aspects will drive the rules and systems that are built.
\end{abstract}

Tujuan penulisan ini adalah untuk membandingkan dan mengevaluasi pemikiran Hans Kelsen dengan Satjïto Raharjo. Keduanya 
menawarkan teori masing-masing, yaitu teori hukum murni Hans Kelsen dan hukum progresif Satjïto Rahardjo. Dalam teori ini, keduanya sama-sama mendasarkan pendekatan secara filosif. Setelah dikaji, teori dari kedua tokoh ini relevan untuk memaknai hukum. Tulisan ini menggunakan paradigima kritis dengan pendekatan kombinasi normatif atau doktrinal dan sosiologis atau non doktrinal. Hasil penelitian menunjukkan bahwa Hans Kelsen lebih mengarahkan pikirannya bahwa positivisme hukum yang menganggap pembicaraan moral, nilai-nilai telah selesai dan final manakala sampai pada pembentukan hukum positif. Teori Hukum Murni bukanlah salinan ide transendental yang sempurna, namun tidak berusaha memandang hukum sebagai anak cucu keadilan. Sementara hukum progresifnya Rahardjo bertumpu pada aspek peraturan dan perilaku (rules and behavior). Peraturan akan membangun suatu sistem hukum positif yang logis dan rasional. Sedangkan aspek perilaku atau manusia akan menggerakkan peraturan dan sistem yang dibangun.

Keywords: Pure Law; Progressive Law; Hans Kelsen; Satjipto Rahardjo.

\section{Introduction}

Hans Kelsen (1881-1973) is a figure of legal positivism that emphasizes that law is a system of norms, based on what it should be (das Sollen). As a product of philosophical thought and study, its true norms in the process of its determination (stipulation) in the form of written (positive) legal regulations, are based on ethical morals and good philosophical values. The basis for determining norms as a category of legal determination is metayuridical. Because of its metayuridical nature, it is inherent in the meaning of das Sollen (what should be). Metayuridical norms are guidelines in social life but do not yet have coercive power. The requirement to become a force force must be followed by an embodiment in the form of written law by an official (state) institution authorized to carry out orders and coercion.

If the moral order does not require compliance with a positive legal order in any situation, or if there is a possibility of a mismatch between the moral order and the legal order, then the argument for the separation between law and moral, between legal and ethical science, means that the 
validity of positive legal norms does not depend on compliance with the moral order; this means that, from the standpoint of knowledge aimed at positive law, legal norms can be considered valid even if they differ from the moral order (Kelsen, 2013: 78).

Laws that have been positivated (realized in the form of written regulations), understood to be finished and final, have effective effectiveness. This understanding puts the moral issues and values considered to have been completed, meaning that it can be understood that morals and values as the noble will of man, are only 'delivering' until the realization of the formulation of written law and after it is finished. The law is free from moral assumptions and values. This understanding by Hans Kelsen gave birth to the formation of Theory of Pure Law (The Pure Theory of Law).

Satjipto Rahardjo (1930-2010), as the initiator of Progressive Law, saw and interpreted the law and its validity, closely related to the dynamics of space, time, social, and intertwined interconnectedness with scholarship outside of scientific knowledge. Law is understood not merely as norms that have been positivated, but laws are inherent in the dynamics of human behavior that are actually inherent and live dynamically in the pulse of human life. The dynamics of human behavior are closely related to the problem of understanding and articulating the norms and values that are believed, which in certain matters of understanding and meaning of this law, there are some differences with the meaning by Hans Kelsen with his Pure Law Theory. According to Adji (Samekto, 2013: 99), "in its development, law, however, should not be closed to developments in thinking in social science. Understanding of developments in social science is important for law. So that the law can increasingly be able to realize its purpose, namely to create justice, prosperity, and life stability".

The law appears in the form of written schemes and behavior. There is not just one way of judging but more, which in its form there is a substantial and artificial way of punishing (Rahardjo, 2009: 49-54). The way to do a substantial punishment starts from the interaction between the members of a community itself which then gives rise to the law. This type is known as interactional law. The interaction is a chemical process that will produce an 
established pattern and ultimately function as law. Whereas artificial law uses written law or legislation as a tool. So the users and legal actors, such as judges, advocates and others, are bound by the regulations, schemes, procedures that have been written down. The perpetrators are not free to see reality in society.

Progressive Law that is carried out by Satjipto Rahardjo, essentially has its own philosophical basis, which when juxtaposed with Hans Kelsen's Pure Law Theory, certainly has a different meaning (including its application) in the realm of legal civilization (humans). Legal thinking by the two Begawan legal scientists (Hans Kelsen and Satjipto Rahardjo) became the basis of study to understand and explore each of them with a critical theory/critical paradigm analysis. Of course both (Theory of Pure Law and Progressive Law) in addition to having different philosophical approaches, but on the other hand there are some similarities. The thoughts of these two figures are very relevant and important to do a study, because of course and surely both have a basis for their participation and validity and usefulness (including its effectiveness) in each civilization and identity to interpret the law.

The formulation of the problem in this paper is:what is Hans Kelsen's thinking about law and Satjipto Rahardjo's ideas about progressive law?; How is Hans Kelsen's analysis of law from the perspective of Critical Legal Theory/Critical Paradigm?; and How is the analysis of Satjipto Rahardjo's ideas about progressive law from the perspective of Critical Legal Theory/Critical Paradigm?

\section{Writing Paradigm}

The writing paradigm* used is the Critical Theory paradigm. Critical Theory Paradigm Analysis (Guba and Lincoln, 1997: 136) includes: 1. Ontology: Historical Realism. A reality is considered to be understood to have once been characterized as flexible, however, from time to time, it is formed by a series of social, political, cultural, economic, ethnic, and gender factors, which then crystallizes (petrified) into a series of structures that are currently (naturally incorrect) is seen as "real", natural and eternal. For practical purposes, the structure is "real", that is, a virtual or historical 
reality; 2. Epistemology: Transactional and Subjectivist. The researcher and the object under study are interactively connected, with the values of the researcher (and the value of "other people" positioned) influencing research inevitably. Therefore, research findings are mediated by values; 3 . Methodology: Dialogical and Dialectical. The transactional nature of research requires dialogue between researchers and research subjects; the dialogue must be dialectically characterized in order to change ignorance and misunderstanding (ie, accepting historically mediated structures as irreversible) into deeper/mature awareness (which is aware of how structures can be changed and understands what actions are needed to produce change) (Indarti, 2004: 191-192).

In the critical paradigm, the real reality is behind the visible. Consequently, the critical paradigm conceptualizes law as reality (a set of legal provisions) which is composed of the results of the dominance of one element over another. The law is thus conceived of as an instrument used by the strong against the weak, for the benefit of the strong. Ontologically, the critical paradigm conceptualizes reality as the construction of relationships that are never balanced. Reality is not represented by the visible. Epistemologically, the researcher seeks to side with the weaker to empower and realize that the situation must be changed to be balanced. The position of the researcher is thus in favor of the object of research (Samekto, 2012: 71).

Critical law study is the idea that law cannot be separated from politics and law is not neutral and value-free. In other words, in the view of Critical Law Study, law in its making, up to its enforcement always contains partiality, even though in a liberal legal order a belief in neutrality, objectivity, predictability in law is formed. Adherents of the Critical Law Study stream intend to dismantle or overturn (overturn) the hierarchical structures in society created by the existence of domination and those efforts will be achieved by using the law as a target. According to the study of Critical Law, domination is legitimized by legal means through hegemony and reification (Samekto, 2008: 91-92). The main objective of the Critical Law Study is to remove obstacles or constraints experienced by individuals who come from social and class structures (in society). With the removal of 
these constraints (it is hoped that) these individuals can empower themselves to develop new understanding of their existence and be able to freely express their opinions (Samekto, 2008: 94). Critical Law Study is a theory that contains opposition to the norms and standards in the theory and practice of law that has so far been accepted. In this case what is meant are legal norms and standards based on the premises of the teaching of liberal legal justice (Samekto, 2008: 104).

Critical legal movements/studies, although only an American phenomenon, they try to package a theory that aims to fight established thinking, especially regarding the norms and standards that have been built into existing legal theories and practices, which tend to be accepted as is (taken for granted), namely legal norms and standards based on the premise of liberal legal justice. Adherents of this school believe that logic and legal structure emerge from the existence of power relationships in society. The importance of law is to support (support) the interests or classes in the society that forms the law (Salman and Susanto, 2008: 125).

The approach used is the normative approach or known as the doctrinal approach, as well as the sociological or non-doctrinal approach. Both of these approaches are used to find a meeting point that in addition to having normative characteristics of law and that law is also not an asocial and cultural process. Law cannot be separated from moral philosophy and other social sciences. Law is an inseparable part from the initiation, formulation, implementation, and evaluation stages of a policy (Warasih, 2005: 211-212). Law, however, should not be closed to developments in thought in social science. Understanding of developments in social science is important for law, so that law can increasingly be able to realize its goal, namely to create justice, prosperity and stability of life (Samekto, 2013: 82).

Law can be studied both from the perspective of legal science or social science, as well as a combination between the two. Socio-legal study is a study of law using the approach of law and social sciences. Therefore an interdisciplinary approach is needed, namely concepts and theories from various disciplines combined and combined to study the phenomenon of law, which is not isolated from the social, political, economic, cultural contexts, where the law is located (Irianto, 2012: 2-3). Interaction between 
jurisprudence and other sciences and human values has resulted in the emergence of a different perspective on law from what was originally only normative to understanding through sociological perspectives. That perspective turns out not only to the theoretical aspects of the law but also to the philosophical aspects of the law (Suteki, 2013: 31). So, in outline that this paper uses a sociolegal approach.

\section{Hans Kelsen's Thoughts on Law and Satjipto Rahardjo's Ideas Regarding Progressive Law}

\section{A. Hans Kelsen's Thoughts on Law}

Hans Kelsen (1881-1973), as a figure of legal positivism, explained the law in the following explanation: Law is a system of norms, a system based on necessities (what should or das sollen). For Hans Kelsen, norms are deliberative products of human thought. Something becomes a norm if it is desired to become a norm, whose determination is based on morality and good values. According to him, the considerations underlying a norm are meta-juridical. Something that is metayuridis is das sollen, and has not become an applicable law binding society. In short for Hans Kelsen, legal norms are always created by will. These norms will become binding on the community, if the norms are desired to become law and must be stated in written form, issued by the authorized institution and containing the instructions (Samekto, 2013: 49).

Hans Kelsen's opinion indicates his thoughts that legal positivism considers moral discussion, values have been completed and final when it comes to the formation of positive law. That is why a very famous fragment of words from Hans Kelsen: the law is obeyed not because it is judged good or fair, but because the law has been written and ratified by the authorities. This is one of the theories introduced by Hans Kelsen in Theory of Pure Law. As a legal theory, The Pure Theory of Law is a positive legal theory, but it is not talking positive law on a particular legal system, but rather a general legal theory. Hans Kelsen's explanation of the Theory of Pure Law aims to explain the nature of law (what is law?) And how the law is made, and not to explain whether the law should (what the law ought to be) or how the law 
should be made. Theory of Pure Law is legal science and not a matter of legal policy (Samekto, 2013: 49-52).

Kelsen departs from Kant's dualism between 'form' and 'material'. Following Kant, Kelsen agrees the difference between the 'existing' field (sein) and the 'must' field (sollen) as two elements of human knowledge (Sinha, 1993). The Sein field deals with nature and facts (all of which are controlled by the formula for cause and effect). While the Sollen field is precisely related to human life (which is controlled by freedom and responsibility). That is why, in the field of Sollen, struggling with freedom and human responsibility. Every human being has freedom, but in living together he bears the responsibility of creating an orderly living together. But to realize an orderly living together, objective guidelines need to be obeyed together as well. These guidelines are called the law. The Sollen field, (where the law is exploited), said Kelsen, is controlled by the principle of dependents (prinzip der zurechnung), which is 'if this happens, then it should also happen' (Hujabers, 1984).

In other words, if the law has determined certain patterns of behavior, then everyone should behave according to the specified pattern. In short, "people must adjust to what has been determined". Herein lies the normative nature of the law. Obligations and obligations to obey the law, merely because it has been determined so (legally-formally), not because of the value contained in the legal material itself. From this we know the term 'juridical-normative' (Tanya, 2003: 115; Ali, 2012; Praja, 2011; Mertokusuma, 2012; Fuady, 2010 and Fuady, 2013).

The question that then arises is, where did the objective guidelines come from? Kelsen said, the source of all that is from grundnorm (basic norms). Grundnorm resembles a presupposition of the 'order' to be realized in living together (in this case, the state). Kelsen himself did not mention the contents of the grundnorm. He only said, grundnorm is a transcendentallogical requirement for the enactment of all legal procedures. All positive legal procedures must be guided hierarchically by grundnorm. Thus, indirectly, Kelsen also actually made a theory about the juridical order (Tanya, 2013: 115). 
If coercion is an essential element of law, then the norm that forms the legal system must be the norm that determines a coercive act, namely sanctions. As part of it, general norms must be norms where certain sanctions are made depending on certain conditions. This dependence is expressed by the concept of necessity (ought). This does not cause the formulation of norms to be done in the form of necessity or prescription ${ }^{* *}$ (Kelsen, 1967: 15-17; Asshddiqie and Safa'at, 2012: 43). Lawmakers can also determine future tense such as "a thief will be punished". Phrases to be punished do not imply predictions of future events, but an imperative or order in the figurative sense (Kelsen, 1961: 45; Asshddiqie and Safa'at, 2012: 43).

It is the duty of jurisprudence to represent the law of a community, that is, material produced by legal authorities in law making procedures, explaining the consequences of the statement that if certain things and certain conditions are met, certain sanctions will follow. This statement must not be mixed with norms made by the law-making authority. Legal norms set by the law-making authority are prescriptive, while the legal rules formulated by the science of law are descriptive (Kelsen, 1961: 71-75; Asshddiqie and Safa'at, 2012: 43).

An 'order' is a system of norms whose wholeness is known from the fact that they all have the same reasons for validity or validity; and the reason for the validity of a norm order is the basic norm which is the source of validity for all norms in that order. A norm is a legal norm that abash if it is in accordance with the concept of "law" and is part of a legal order or system; and it is part of the legal order if its validity is based on the basic norms in that order (Kelsen, 2013: 35).

These legal norms regulate the behavior of people who could be threatened with punishment. This behavior can be positive or non-action (ie not taking action, omission, avoidance, stopping action). The legal order, as a social order, positively regulates the behavior of individuals as long as this behavior is directed, directly or indirectly, to other individuals. The object governed by the legal order is the behavior of one individual in relation to one, several, or all other individuals-reciprocal behavior between individuals. The relationship of one person's behavior with another may be 
individualized: for example, the norm that requires everyone not to kill another person; or norms that require debtors to repay their debts to creditors; or norms that require everyone to respect the property of others. But that relationship can also have a collective character.

For example, the behavior established by the norm that requires a person to undergo military service is not the behavior of an individual towards other individuals, but rather of the entire social community - of all individuals who are subject to the legal order. The same thing happened where suicide attempts could also be subject to punishment. The legal authority orders certain human behavior, because that authority, rightly or wrongly considers that behavior necessary for the human legal community. In the end, the connection to the legal community is crucial for the legal regulation of the behavior of one individual towards another individual (Kelsen, 2013: 36).

Understanding legal positivism, according to Hans Kelsen, is interpreted as (Suherman, 2004: 37-38): first, legal positivism as a method (as a way of studying law as a complex fact, phenomenon or social data and not, as a value system, as a method that sets the center for inquiry into formal problems of legal validity, not the axiology of justice from a norm/rule content). Second, legal positivism which is understood as a theory (this understanding is called an imperativist group, coercivist, legalist conception which is enforced through literal law (written), interpretation of written norms mechanically by translators, especially judges). Third, legal positivism as an ideology (that state law is obeyed in an absolute manner which is concluded in a gesetz ist gesetz statement or the law is the law.

\section{B. Satjipto Rahardjo's Idea Regarding Progressive Law}

Satjipto Rahardjo (1930-2010) (Kompas, 2002; Tanya, 2013: 190), as the initiator of the Progressive Legal Theory, who was troubled by the way law was administered in Indonesia. Although every time legal issues arise in a transitional nuance, the implementation of the law continues to be carried out like normal conditions. There are almost no smart breakthroughs facing the turmoil of the post-New Order transition. Even more alarming, the law is not only run as a routine (business as usual), but also mocked as 
'merchandise' (business-like). As a result, the law was pushed into the slow lane and experienced quite serious bottlenecks. From here Satjipto voiced the need for progressive law.

According to Satjipto Rahardjo, legal thinking needs to return to its basic philosophy, which is law for humans (Rahardjo, 2004). With this philosophy, humanity becomes the determinant and legal orientation point. The law is in charge of serving humans, not vice versa. Therefore, the law is not an institution that is free from human interests. The quality of law is determined by its ability to serve human welfare. This causes progressive law to adopt an 'ideology': a law that is pro-justice and a law that is propeople (Rahardjo, 2004). With this ideology, the dedication of legal actors takes first place to recover. The perpetrators of the law are required to promote honesty and sincerity in law enforcement. They must have empathy and care for the suffering experienced by the people and this nation. The interests of the people (their welfare and happiness) must be the point of orientation and the ultimate goal of the administration of law (Tanya, 2013: 190).

It is in this logic that legal revitalization is carried out every time. For progressive law, the process of change is no longer centered on regulations, but on the creativity of legal actors actualizing the law in the right time and space. Progressive legal actors can make changes by making creative meanings of existing regulations, without having to wait for changes in regulations (changing the law). Bad regulations do not have to be a barrier for progressive legal actors to bring justice to the people and justice seekers, because they can make new interpretations every time for a regulation (Tanya, 2013: 191).

The power of progressive law is a force that rejects and wants to break the status quo. Maintaining the status quo is accepting normativity and the existing system without any effort to see the various weaknesses in it, then act to overcome. There is almost no attempt to make improvements, there are only carrying out the law as it is and on an "ordinary" basis (business as usual) (Rahardjo, 2007: 114-115).

Living the law is not the same as applying the rules of the letter just like that, but looking for and finding the true meaning of a rule. Looking for law 
in regulations is to find the meaning and value contained in regulations and not just read them "flat" just like that. The law is not a telephone book that only lists rules and articles, but something that is loaded with meaning and value. Reading rules evenly is solving problems by using rational intelligence alone (Rahardjo, 2007: 20).

Several times have been reminded, modern law (indeed) is designed in a formally-rational and that has its own risks. The risk is, the law will be run based on formal-rational benchmarks. In this way the true meaning contained in the regulations, it does not need to be searched further. Proverbial, simply push the button, the decision has been made correctly. We do not need to bother trying to find the meaning, value, and moral content behind it (Rahardjo, 2007: 21).

The situation has now changed, also in the variety of human thinking, as happened in psychology (and psychiatry). The way of thinking to solve problems that are accepted as "perfect" intelligence is spiritual thinking, which seeks and questions that meaning. As Zohar and Marshall said in the book above, "... Spiritual intelligence inspires our moral sense, by providing an ability to control rigid provisions through understanding and understanding (Rahardjo, 2007: 21).

Satjipto also explained about law as text and behavior. Law as a scheme is law as found in texts or laws or laws that are deliberately formulated rationally. Here the law has undergone a shift in form, from the law that emerged and also (interactional law) to the law that was made and enacted (legislated law). Since it became law in the form of text, language takes a major role. Law is something in the form of language (talig, Dutch) or a language game. Without realizing it or realizing it, the way of law has entered a new dimension, namely to do justice/through a scheme. The legal stage has also shifted from the real world to cyberspace which consists of sentences and words (Rahardjo, 2010: 7).

The shift can also be interpreted as a development from something whole into something reduced. Every time we make a written formula, each time we also reduce a whole idea into the sentence structure. Making written law is not the same as moving reality perfectly into the text, so that a perfect equivalent occurs, but rather "translating that reality into sentences". 
The sentences reduce a whole idea into a scheme, framework or skeleton. People who were originally intact have been redefined into one scheme. In the formulation process there must be aspects scattered (Rahardjo, 2010: 8).

One important characteristic of written law lies in its rigidity (Lex dura sed tamen scripta-law is hard / rigid, but that is the nature of written). Once the law was written down or became a written document, attention shifted to the complexity of its use as a written document. If originally the law was related to the issue of justice or the search for justice, then now we are faced with the text, reading the text, the meaning of the text, and others (Rahardjo, 2010: 9).

When the concept of law turns into law by text, then there is a tunnel that becomes closed or at least narrows. The hallway is law with common sense (fairness, reasonableness, common sense). Law based on texts has a strong tendency to rule in a rigid and regimental manner. Such a method of law, especially those that are excessive, raises a variety of major problems, especially in relation to achieving justice. If we say that the law is flawed from birth, then the cause of the defect is because we formulate a substance, an idea, into sentences, words or language. Every time we try to formulate an idea in our heads, every time we have to deal with a defective formulation. There are always parts, elements, cirri, scattered, which are unspeakable and intact through these words (Javanese, mrojol) (Rahardjo, 2010: 10).

When attention in legal studies moves away from the bookshelves where the legal documents are stored while arguing that the law is there and then plunging into daily life, a very big change occurs. At that time, understanding (understanding) the law as a text or written document, received a total correction. It turns out that the legal texts cannot be fully trusted as an authentic representation of legal life. To be able to see human behavior as law, we need to be willing to change our concept of law, which is not only as a rule, but also behavior. As long as we insist, that the law is a rule and nothing else, it is difficult to understand, that the law also appears in the form of behavior. Law as a text is silent and it is only through human 
mediation that it becomes "alive" (Rahardjo, 2010: 13-15; Rahardjo, 2009: 19-29).

\section{Analysis of Hans Kelsen's thoughts on law from the perspective of Critical Legal Theory}

The main focus of Pure Legal Theory, according to Hans Kelsen, is not a copy of transcendental ideas which is more or less imperfect. This Pure Law Theory does not try to see the law as a posterity of justice, as a child of a sacred parent. Legal theory seems to hold firm a distinction between empirical law and transcendental justice by removing transcendental justice from its specific attention. This theory does not see the manifestation of an occult authority in law, but rather looks at a specific social technique based on human experience; pure legal theory refuses to be made into legal metaphysics (Dimyati, 2010: 74-75).

Cleansing or purifying the law from non-legal elements (epsithemologically) is the final and absolute basis for Kelsen. Many people call Hans Kelsen as the foundation of theory and legal science into an independent discipline (autonomus discipline). This epistemological foundation of Hans Kelsen has until now invited debate, including within the faculty of law in the country. There are two important theories put forward by Hans Kelsen that influence legal thinking (Putro, 2013: 19-20): first, the legal imperatives are pure. Law must be separated from morals, so that the purpose of law is only one, namely legal certainty. Rights and obligations according to Kelsen, only exist if determined by legal norms (positive law). The rule of law is obligatory because of its formal aspects (Hujabers, 1990: 16).

Second, Kelsen rejects if the validity of a norm is tested for something that is not the norm. The consequence of Kelsen's thought in interpreting norms gave birth to the theory of levels (Stufenbau des Recht) that legal norms are arranged in stages. Stufenbautheorie teaches that the legal system is hierarchical in which a certain legal provision comes from other higher legal provisions. What is meant by a higher provision is a grundnorm or basic norm that is hypothetical. Lower provisions are more concrete legal provisions than higher ones. Higher norms become sources of lower norms 
(Kelsen, 1961: 124). The problem only arises when he reaches the top of the hierarchical system, which Kelsen gives the name grundnorm (basic norms). The discourse on basic norms and fundamental norms of this country has actually "trapped" Kelsen to the teachings of abstract natural law (norm abstraction). Apart from Kelsen's objections to being equated with the concept of Natural Law Flow, the concept of grundnorm which he proposes opens a little gap from the solidity of argumentation and the closure of his logical system, that positive norms have a peak that functions regulatively and constitutively. The hierarchical system shows the levels of norm abstraction. As a result, this basic norm is at the highest level of abstraction, which plays in the boundary area between law and morals (Sidarta, 2006: 247-248).

As is the case with Dogmatic Law, whose "dogmatic" character lies in the fact that people truly limit themselves to a specific legal system. People limit themselves to certain positive legal rules, and close themselves to other legal systems (Sidarta, 2009: 54). The truth in jurisprudence is actually more constructed than discovered by subjects, and is accounted for by subjects related to the legal forum (theorists and legal practitioners) rationally. Therefore, the truth in law is more normative, discursive, subjective and constructivist (Sidarta, 2013: 93; Otto, 2008; Anshori, 2008).

Modernism has encouraged the use of reason and reason so strongly. Thoughts or works based on the use of reason and reason are greatly admired. Science (especially natural science) and its scientific methods are highly admired. Begins to develop the view that what is true is concrete. This view underlies the birth of the philosophy of positivism, which developed very rapidly in the XVIII-XIX centuries (Samekto, 2005:22).

The philosophy of positivism is based on something that is real, tangible, concrete, visible, not based on a metaphysical system. The philosophy of positivism does not want to explain the essence, because the essence is something abstract. Essence can be related to value or interpretation, something which is invisible. Therefore positivism does not explain the essence. The philosophy of positivism - once again - is based only on reality and only uses the scientific method (Samekto, 2005: 22-23). 
Soetandyo (Samekto, 2005: 8) stated that the positivation of legal norms is a political process that is crucial for the development of law as an applied art. These legal teachings with texts developed as doctrines (such as neutrality and objectivity of the law) have been standardized since the early 19th century. Legal doctrines inspired by positivism paradigms such as law are neutral, impartial, impersonal, and objective with their descriptions in the principle of equality before the law, for example, becoming teachings that cannot be denied and become an integral part in legal education material (including in legal Indonesia).

The Saintification of modern law is strongly influenced by the emergence of the positivism paradigm in modern science. The main character of modern law is its rational nature. This rationality is characterized by procedural legal nature. Procedure, thus becomes an important basis for legality to uphold what is called justice, even the procedure becomes more important than talking about justice itself. In the modern legal system justice (justice) has been considered given by making positive law. However, in practice, the use of the positivism paradigm in modern law also creates many rigidity in such a way that searching for the truth and searching for justice is not achieved because it is blocked by procedural walls (Samekto, 2005: 9-10).

The next characteristic of positivism is that it is objective or value-free. That is why, said Donny Gahral Adian (2001: 36), in (paradigm) positivism there is a strict dichotomy between facts and values, and requires the research subject to distance himself from reality by being neutral (Samekto, 2005: 33). However, human behavior can change according to the factors that influence it. Social phenomena naturally are subjective and cannot be understood as objective. It is quite clear that Santos said, human behavior cannot be described and described based on its external characteristics. Human characteristics cannot be objectified because actions that appear to be (externally) alike can lead to diverse interpretations. The social sciences will thus always be subjective knowledge and according to Santos (tt: 16-17), there must be an understanding of the attitude and meaning of action. 


\section{Analysis of Satjipto Rahardjo's from the perspective of Critical Legal Theory}

The word 'progressive' comes from progress, which means progress. The law is expected to be able to keep up with the times, be able to answer the changing times with all the bases in it, and be able to serve the community by relying on the moral aspects of the law enforcement human resources themselves (Rahardjo, 2007:228). There are plenty of reasons to say that jurisprudence holds untruth and bias. Many epistemological questions can be asked of him, such as whether it is right to call the liberal characteristics of modern law as standard? Why must modern laws that have their own distinctive histories be accepted and imposed on nations that have different social histories? Why should such principles, doctrines, and concepts be held? (Rahardjo, 2004: 99-100).

Positive legal theory only highlights and talks about a part of a large order, which is included in the political order and more specifically the statebased order. It is unacceptable to have another order that cannot be linked to that country, even if that type of order exists in society. Acceptance of another type of order outside the positive will disturb the truth of the rational system of the theory. This is very contrary to the scientific attitude that starts from observation of what really exists in society (Rahardjo, 2000: 19).

If legal positivism sees law as final, Progressive Law says otherwise: law cannot be called an absolute and finished type of law. Progressive Law assumes that legal institutions are always in the process of continuing to become (law as process, law in the making). Progressive law can be described as a signboard, which always warns, it must continually break down, replace, free up stagnant laws, because it is unable to serve the changing environment. Therefore, according to Satjipto Rahardjo, judges must have the courage to do a rule breaking, that is, dare to make progressive legal breakthroughs, in order to help the nation and its country from adversity (Rahardjo, 2007; Putro, 2011: 98).

Progressive law does not accept law as an absolute and final institution, but is largely determined by its ability to serve humans. In that context of thought, law is always in the process of continuing to be. Law is an 
institution that continually builds and transforms itself towards a better level of perfection. The quality of perfection can be verified in terms of justice, welfare, concern for the people and so on. This is the nature of the law which is always in the process of becoming (Rahardjo, 2010: 1; Putro, 2011: 98).

If legal positivism teaches law for law, on the contrary Progressive Law follows the maxim, "Law is for humans and society, not law for law". The statement of law is for humans to mean that law is a means to make people happy. If when there is a problem in law, then the law must be reviewed and corrected, not humans who are forced to be included in the legal scheme. The law can never serve humans if it does not also work with feeling and care (compassionate). To be able to serve humans well, the law cannot only calculate and spell out articles of the law, but also work with capital of empathy and courage (dare) and that has not been able to be done with machines (Rahardjo, 2007: 107; Putro, 2011: 98).

A progressive legal orientation relies on the aspects of rules and behavior (rules and behavior). Regulations will build a positive and rational legal system. While the behavioral or human aspects will drive the rules and systems that are built. Satjipto Rahardjo seems to focus more on the behavioral aspects than the rules by quoting Taverne's words, "Give me a good prosecutor and judge, then even with bad rules I can make good decisions." (Putro, 2011: 98).

Disputes of thought between Legal Positivism and Progressive Law culminated, when Progressive Law began to enter the most "sacred" area for legal positivism, namely: legal certainty. The ideology of legal certainty obtains justification or theoretical support from legalistic legal thinking. Legal certainty, according to Satjipto Rahardjo's knife of analysis, goes hand in hand with the desire to maintain the status quo. This situation requires all to be fixed in their respective places or boxes, without giving almost any leeway to get out of the boxes. The ideology of legal certainty is in favor of a final world (finite scheme), where the dynamics or movements will shake and tear down the ideology and therefore "must be muted" (Putro, 2011: 9899). 
Behind Progressive Legal disputes and Legal Positivism, there is a kind of paradox. Legal Positivism is at the heart of Modern Law. Criticism of modern law, criticism must be directed at its heart, namely Legal Positivism. That is why Progressive Law criticizes Modern Law by criticizing Legal Positivism. But Progressive Law contains a kind of paradox. Progressive Law which makes a critique of Modern Law, none other than the spirit of modernism, namely progressiveness. The character of modernism is "progressive" itself. Progressive as a character of modernism tends to disqualify the past and always strives towards novelty and progress. When modernism continually pursues novelty, it then always looks for a form of compensation. But because it does not find the essence, so that its existence is recognized, modernism covers it with fashion (Putro, 2011: 100).

Dualism and reductionists have damaged the understanding of law, both as a science and as a practical phenomenon. The jurisdiction is seen as an area of empiricism and rationalism which has subsequently fostered the bloom of positive law, with its credibility of rules and logic. Jurisprudence only sees law as a logical-rational structure or structure, so that the focus is only on formulating specific definitions, classifying and classifying, systematizing, and merely applying to the law. The science of law as a science whose conditions of value and symbolic meaning become dry science, because of the use of an approach where the subject is outside of the object being studied (Susanto, 2010: 35-36). The legal myth that has grown from the conception of order for a sterile, liberal and positivistic view will in fact become a kind of myth in a level that has never materialized and has never been down to earth. He will be farther and farther behind reality (Susanto, 2005: 123-124). The reductionist nature is another feature that can be found in legal positivism thinking. This assumption states, the object of study is a unit of composition that can be reduced to small parts (Susanto, 2010: 157).

Progressive Legal Philosophy and Critical Legal Theory have the same attitude towards power. An attitude of suspicion that is fundamental to the regime of power is demonstrated by the Progressive Legal Philosophy and Critical Legal Theory that law should not maintain the status quo in the way it is punished. This will show that an established legal institution will easily 
become a hiding place from stretching the interests of the powers that play in it. So Satjipto considered that the Critical Legal Theory (critical legal studies) originated from the strength of the left movement against the established legal regime (Marwan, 2013: 359).

Satjipto believes that the theoretical basis of the critical legal movement is not a class theory that inspires adherents of critical movements throughout the world. He believes that the epistemological basis of the critical legal movement is social science, which opens the taps for the analysis of the legal regime from the viewpoint of sociology, anthropology, politics, economics, and so on. In this context too, Satjipto readers also laid a different foundation for progressive legal theory. On the other hand progressive law schools have a knife of analysis that can slice up the status quo, perfectly suited to the world of anti-establishment movements. However, on the other hand, the readers of Satjipto's books, mainly from academics, position this idea in a neutral, scientific, and objective sector. Finally, progressive law used by bureaucrats even established professional lawyers, progressive law can even be said as an instrument of legitimacy of power that wants to crash into existing procedures (Marwan, 2013: 365).

In some general literature which almost everyone has read, the law is always raised and described as a process from the 'crisis' condition to a better situation. Likewise Satjipto Rahardjo when giving an explanation of the ongoing paradigmatic changes about the law that is increasingly progressive (Susanto, 2007: 121).

\section{Conclusion}

The discussion of Hans Kelsen's thoughts on law and Satjipto Rahardjo's ideas on progressive law (analysis of critical theory paradigm/critical paradigm), concluded as follows:

1. Hans Kelsen indicated his thoughts that legal positivism considers moral discussion, values completed and final when it comes to the formation of positive law. That is why a very famous fragment of words from Hans Kelsen: the law is obeyed not because it is judged good or fair, but because the law has been written and approved by the authorities. This is one of the theories introduced by Hans 
Kelsen in Theory of Pure Law. Meanwhile, according to Satjipto Rahardjo, legal thinking needs to return to its basic philosophy, which is law for humans. With this philosophy, humanity becomes the determinant and legal orientation point. The law is in charge of serving humans, not vice versa. Therefore, the law is not an institution that is free from human interests. The quality of law is determined by its ability to serve human welfare.

2. The Pure Legal Theory by Hans Kelsen is not meant to be a copy of a transcendental idea that is more or less imperfect. This Pure Law Theory does not try to see the law as a posterity of justice, as a child of a sacred parent. Legal theory seems to hold firm a distinction between empirical law and transcendental justice by removing transcendental justice from its specific attention. This theory does not see the manifestation of an occult authority in law, but rather looks at a specific social technique based on human experience; pure legal theory refuses to be made into legal metaphysics. Cleansing or purifying the law from non-legal elements (epsithemologically) is the final and absolute basis for Kelsen. Many people call Hans Kelsen as the foundation of theory and legal science into an independent discipline (autonomus discipline). This epistemological foundation of Hans Kelsen has until now invited debate, including within the faculty of law in the country.

3. The progressive legal orientation carried out by Satjipto Rahardjo rests on the aspects of rules and behavior. Regulations will build a positive and rational legal system. While the behavioral or human aspects will drive the rules and systems that are built. Disputes of thought between Legal Positivism and Progressive Law culminated, when Progressive Law began to enter the most "sacred" area for legal positivism, namely: legal certainty. The ideology of legal certainty obtains justification or theoretical support from legalistic legal thinking. Legal certainty, according to Satjipto Rahardjo's knife of analysis, goes hand in hand with the desire to maintain the status quo. This situation requires all to be fixed in their respective places or boxes, without giving almost any leeway to get out of the boxes. 
The ideology of legal certainty is in favor of a final world (finite scheme), where the dynamics or movements will shake and tear down the ideology and therefore "must be muted". [w]

\section{Noted:}

*The true paradigm is a philosophical system 'umbrella' which includes a specific ontology, epistemology and methodology. Each of them consists of a series of 'basic beliefs' or worldviews that cannot simply be exchanged (with 'basic beliefs' or worldview from ontology, epistemology, and other paradigm methodologies).

** This requirement or prescription can be adhered to either positively or negatively in the form of commands (commanding), authorization and also permitting

\section{Reference}

Adian, Donny Gahral. 2001. Arus Pemikiran Kontemporer: Atheisme, Positivisme Logis, Neo Marxisme. Yogyakarta: Jala Sutra.

Ali, Achmad and Heryani, Wiwie. 2012. Sosiologi Hukum Kajian Empiris terhadap Pengadilan. Jakarta: Kencana.

Ali, Achmad. 2008. Menguak Tabir Hukum. Bogor: Ghalia Indonesia.

Ali, Achmad. 2012. Menguak Teori Hukum dan Teori Peradilan, Jakarta: Kencana.

Anshori, Abdul Ghofur, dkk. 2008. Membangun Hukum Indonesia. Yogyakarta: Total Media.

Asshiddiqie, Jimly and Safa'at, M Ali. 2012. Teori Hans Kelsen tentang Hukum. Jakarta: Konpress.

Denzin, N.K. and Lincoln, Y.S. (eds). 1997. Handbook of Qualitative Research, London: Sage Publications, Inc. 
Denzin, N.K. and Lincoln, Y.S. "Introduction: Entering the Field of Qualitative Research" dalam Denzin, N.K. dan Lincoln, Y.S. (eds). 1994. Handbook of Qualitative Research. London: Sage Publications, Inc.

Dimyati, Khudzaifah. 2010. Teorisasi Hukum. Yogyakarta: Genta Publishing.

Friedmann, W. 1990. Teori dan Filsafat Hukum. terj. Muhamad Arifin. Jakarta: Rajawali Pers.

Fuady, Munir, 2013. Teori-Teori Besar dalam Hukum. Jakarta: Kencana.

Fuady, Munir. 2010. Dinamika Teori Hukum. Bogor: Ghalia Indonesia.

Huijbers, Theo. 1984. Filsafat Hukum dalam Lintasan Sejarah. Yogyakarta: Yayasan Kanisius.

Indarti, Erlyn, "Bertemu Ruas dengan Buku, Menelusuri Benang Merah antara Gagasan Fritjof Capra dan Konstruktivisme", dalam Widianarko, Budi. Dkk. 2004. Menelusuri Jejak Capra, Yogyakarta: Kanisius.

Indarti, Erlyn. 2010. Diskresi dan Paradigma Sebuah Telaah Filsafat Hukum (Pidato Pengukuhan Guru Besar dalam Filsafat Hukum). Semarang: Undip.

Irianto, Sulistyowati and Shidarta (ed). 2013. Metode Penelitian Hukum Konstelasi dan Refleksi. Jakarta: Yayasan Pustaka Obor Indonesia.

Irianto, Sulistyowati. 2012. Memperkenalkan Kaj̈an Sosiolegal dan Implikasi Metodologisnya. Bali: Pustaka Larasan.

Kelsen, Hans, 2013. Teori Hukum Murni. terj. Raisul Muttaqien. Bandung: Nusa Media.

Kelsen, Hans. 1961. General Theory of Law and State. Translated by: Anders Wedberg. New York: Russel \& Russel.

Kelsen, Hans. 1967. Pure Theory of Law. Translated by: Max Knight, Berkeley, Los Angeles, London: University of California Press.

Mahfud, Moh dkk. 2013. Dekonstruksi dan Gerakan Pemikiran Hukum Progresif. Yogyakarta: Thafa Media-Satjipto Rahardjo Institute. 
Marwan, Awaludin. 2013. Satjïto Rahardjo Sebuah Biografi Intelektual dan Pertarungan Tafsir terhadap Filsafat Hukum Progresif. Yogyakarta: Thafa Media-Satjipto Rahardjo Institute.

Menski, Werner. 2012. Perbandingan Hukum dalam Konteks Global. terj. M. Khosim. Bandung: Nusa Media.

Mertokusumo, Sudikno. 2012. Teori Hukum. Yogyakarta: Cahaya Atma Pustaka.

Otto, Jan Michiel dkk. 2008. Butir-Butir Pemikiran dalam Hukum. Bandung: Refika Aditama.

Praja, Juhaya S. 2011. Teori Hukum dan Aplikasinya. Bandung: Pustaka Setia.

Putro, Widodo Dwi. Kritik Terhadap Paradigma Positivisme Hukum. Yogyakarta: Genta Publishing.

Rahardjo, Satjipto. 2000. Ilmu Hukum, Bandung: Citra Aditya Bakti.

Rahardjo, Satjipto. 200o. Mengajarkan Keteraturan Menemukan Ketidakteraturan, Semarang: Undip.

Rahardjo, Satjipto. 2000. Sisi-sisi Lain dari Hukum di Indonesia. Jakarta: Kompas.

Rahardjo, Satjipto. 2004. Ilmu Hukum, Pencarian, Pembebasan, dan Pencerahan. Surakarta: Muhammadiyah University Press.

Rahardjo, Satjipto. 2007. Biarkan Hukum Mengalir: Catatan Kritis tentang Pergulatan Manusia dan Hukum. Jakarta: Kompas.

Rahardjo, Satjipto. 2009. Hukum dan Perilaku. Jakarta: Kompas.

Rahardjo, Satjipto. 2009. Membangun dan Merombak Hukum Indonesia Sebuah Pendekatan Lintas Disiplin. Yogyakarta: Genta Publishing.

Rahardjo, Satjipto. 2009. Pendidikan Hukum sebagai Pendidikan Manusia. Yogyakarta: Genta Publishing,.

Rahardjo, Satjipto. 2010. Pemanfaatan Ilmu-Ilmu Sosial bagi Pengembangan Ilmu Hukum. Yogyakarta: Genta Publishing, Yogyakarta.

Rahardjo, Satjipto. 2010. Penegakan Hukum Progresif. Jakarta: Kompas.

Rahardjo, Satjipto. Membedah Hukum Progresif. Jakarta: Kompas. 
Salman, HR Otje and Susanto, Anthon F. 2008. Teori Hukum. Bandung: Refika Aditama.

Samekto, Adji. 2005. Studi Hukum Kritis Kritik Terhadap Hukum Modern. Bandung: Citra Aditya Bakti.

Samekto, Adji. 2008. Justice Not For All Kritik Terhadap Hukum Modern dalam Perspektif Studi Hukum Kritis. Yogyakarta: Genta Press.

Samekto, Adji. 2012. Ilmu Hukum dalam Perkembangan Pemikiran Menuju Post Modernisme. Bandar Lampung: Indepth Publishing.

Samekto, Adji. 2013. Hukum dalam Lintasan Sejarah. Bandar Lampung: Indepth Publishing.

Shidarta dkk. 2012. Mochtar Kusuma Atmadja dan Teori Hukum Pembangunan. Jakarta: Epistema Institute-Huma.

Shidarta. 2013. Hukum Penalaran dan Penalaran Hukum. Yogyakarta: Genta Publishing.

Sidharta, Bernard Arief. 2009. Mauwissen tentang Pengembanan Hukum, Ilmu Hukum, Teori Hukum, dan Filsafat Hukum. Bandung: Refika Aditama.

Sidharta, Bernard Arief. 2013. Ilmu Hukum Indonesia. Yogyakarta: Genta Publishing.

Sinha, Surya Prakash. 1993. Jurisprudence Legal Philosophy in A Nutshell. Minessota: West Publishing Co.

Suherman, Ade Maman. 2008. Pengantar Perbandingan Sistem Hukum. Jakarta: Rajawali Pers.

Susanto, Anthon F. 2005. Semiotika Hukum dari Dekonstruksi Teks Menuju Progresivitas Makna. Bandung: Refika Aditama.

Susanto, Anthon F. 2007. Hukum dari Consilience Menuju Paradigma Hukum Konstruktif-Transgresif. Bandung: Refika Aditama.

Susanto, Anthon F. 2010. Dekonstruksi Hukum Eksplorasi Teks dan Model Pembacaan. Yogyakarta: Genta Publishing.

Susanto, Anthon F. 2010. Ilmu Hukum Non Sistematik Fondasi Filsafat Pengembangan Ilmu Hukum Indonesia. Yogyakarta: Genta Publishing.

Suteki. 2013. Desain Hukum di Ruang Sosial. Yogyakarta: Thafa Media. 
Tanya, Bernard L,dkk. 2013. Teori Hukum Strategi Tertib Mamusia Lintas Ruang dan Generasi. Yogyakarta: Genta Publishing.

Warassih, Esmi. 2005. Pranata Hukum Sebuah Telaah Sosiologis. Semarang: Suryandaru Utama.

Wignyosoebroto, Soetandyo. 2000. Perubahan Paradigma dalam Ilmu Hukum pada Masa Peralihan Millenium (dari Abad ke-2o ke Abad ke-21, Makalah. Semarang: Undip. 